Yasuko Yamanouchi • Takako Takano

Hideo Hamaguchi • Katsushi Tokunaga

\title{
A novel apolipoprotein E5 variant with a 24-bp insertion causing hyperlipidemia
}

\begin{abstract}
A tandem 24-bp insertion in the apolipoprotein E (apo $E$ ) gene was detected in a patient with elevated triglyceride, apolipoprotein (apo) CII, and apo CIII levels. This novel variant, apo E5ss, showed in position apo E5 by isoelectric focusing and was of larger molecular weight than apo E3 during two-dimensional gel electrophoresis. Polymerase chain reaction-single strand conformation polymorphism analysis using the primer pairs that cover all the coding regions was useful for rapid detection of the variant of the apo E allele. Apo E5ss may have a 24-bp insertion caused by slipped mispairing, resulting in a tandem duplication of amino acid residues 135-142 [APOE, 24-BP INS, DUP CODONS 135-142]. The proband was the only person with apo E5ss among the 806 Japanese males that we examined. We inspected six other reported apo E5 variants in the literature.
\end{abstract}

Key words Apolipoprotein E - Apo E5 - Hyperlipidemia · Insertion - Tandem duplication - PCR-SSCP . Twodimensional gel electrophoresis · Variant

Y. Yamanouchi $\cdot$ T. Takano $(\square)$

Department of Hygiene and Public Health, Teikyo University School of Medicine, 2-11-1 Kaga, Itabashi-ku, Tokyo 173-8605, Japan

Tel. +81-3-3964-1211 ext. 2169; Fax +81-3-3964-1058

e-mail: takako@med.teikyo-u.ac.jp

H. Hamaguchi

Department of Medical Genetics, Institute of Basic Medical Science, University of Tsukuba, Tsukuba, Japan

K. Tokunaga

Department of Human Genetics, School of International Health, University of Tokyo, Tokyo, Japan

${ }^{1}$ The notation of three small letters such as apo E follows the classification of apolipoprotein based on isoelectric focusing. Apo $\varepsilon$ indicates the apolipoprotein genotype. APOE shows the allelic variant if amino acid substitution can be clarified by sequencing. The allelic variant was coded according to McKusick (1998, OMIM).

\section{Introduction}

Apolipoprotein $\mathrm{E}$ (apo $\mathrm{E}^{1}$ ) is a constituent of chylomicrons, chylomicron remnants, very-low-density lipoproteins (VLDL), intermediate-density lipoproteins (IDL), and high-density lipoproteins (HDL). It plays an important role as a ligand for the apo $\mathrm{E}$ receptor-mediated uptake of VLDL in the catabolism of triglyceride-rich lipoproteins. It also functions as a ligand for the cholesterol uptake of IDL and low-density lipoproteins (LDL) through an interaction with LDL receptors (Mahley 1988). Human apo E is composed of 299 amino acid residues and has a molecular weight of 34,200 . In plasma, there are three common isoforms of apo E: apo E2, E3, and E4. The classification of the isoforms of apo $\mathrm{E}$ has been based on the global charge of the protein per one unit and determined by isoelectric focusing (IEF) (Zannis et al. 1981; Utermann et al. 1980; Mahley 1988). According to the reverse order of the mobility of IEF, other isoforms have been designated by the name "apo E1" to "apo E7". Apo E3 is the most commonly occurring isoform encoded by the apo $\varepsilon 3$ genotype.

Compared with the apo E3 isoform, the apo E4 isoform has a Cys $\rightarrow$ Arg substitution at position 112, and the apo E2 isoform has an Arg $\rightarrow$ Cys substitution at position 158. The receptor-binding domain was formerly reported to be in the vicinity of amino acid residues 133-160 of apo E3 (Rall et al. 1982a; Lalazar et al. 1988). Compared with the apo E3 isoform, apo E2 [APOE, R158C] has a decreased functional catabolic rate and exhibits markedly impaired binding to the LDL receptor (Weisgraber et al. 1982). Type III hyperlipoproteinemia (HLP) is caused by homozygosity for apo E2 [APOE, R158C] (Breslow et al. 1982). In patients with type III hyperlipoproteinemia, various mutations of a Cys residue were reported (Havel et al. 1983; Rall et al. 1989). On the other hand, apo E4 [APOE, C112R] is known to be related to elevated levels of plasma total cholesterol (TC) and LDL-cholesterol (LDL-C), even though apo E4 [APOE, C112R] and apo E3 have similar binding activities for the LDL receptor (Weisgraber et al. 1982). 
Furthermore, various mutations of the commonly occurring apo E3 as determined by IEF were reported. Thus, it is increasingly important to clarify the genotype of apolipoproteins by sequencing. Moreover, aside from hyperlipidemia, apo E4 [APOE, C112R] is known to be a major risk factor for Alzheimer's disease (Corder et al. 1993; Saunders et al. 1993; Poirier et al. 1993; Noguchi et al. 1993; Yoshizawa et al. 1994).

Apo E5 has been designated by the fact that the isoelectric point (PI) of the main spot of apo E5 shifts two charge units away from that of the apo E3 spot by IEF. Apo E5 [APOE, E3K] was first detected in a Japanese patient with hyperlipidemia. It migrates faster than apo E3 during sodium dodecyl sulfate-polyacrylamide gel electrophoresis (SDS-PAGE) (Yamamura et al. 1984; Tajima et al. 1988; Maeda et al. 1989). The receptor binding activity of apo E5 [APOE, E3K] is about twice that of apo E3 (Dong et al. 1990; Wardell et al. 1991). There have been several reports of apo E5 mutations such as apo E5 [APOE, E13K], apo E5 [APOE, Q81R AND C112R], apo E5 Frankfurt [APOE, P84R AND C112R], apo E5 [APOE, E212K], and apo E5s (Mailly et al. 1991; Ruzicka et al. 1993; Feussner et al. 1996; Yamanouchi et al. 1994) In addition, the gene frequency of apo $\varepsilon 5$ was about 0.005 , which was the highest next to those of the common apo E alleles $(\varepsilon 3, \varepsilon 4$, and $\varepsilon 2)$ and apo $\varepsilon 7 . \mathrm{We}$ have already reported apo E5s detected by two-dimensional electrophoresis (2-DE) (Yamanouchi et al. 1994). In this study, we present another novel apo E5 variant, E5ss. We applied the polymerase chain reaction-single strand conformation polymorphism (PCR-SSCP) analysis and the sequencing using our primer pairs to detect all the variants throughout the entire protein-coding sequence of apo E. We describe the characterization of apo E5ss and the mechanism of the 24-bp tandem duplication, and compare this variant with the other six reported apo E5 variants whose nucleotide sequences are in the literature.

\section{Proband and methods}

\section{Proband}

The proband was a 57-year-old Japanese man (body mass index $=23.6$ ) who had a history of gastric surgery. Blood samples from the proband after overnight fasting were obtained with his informed consent. His lipid levels indicated hyperlipidemia (TC, $181 \mathrm{mg} / \mathrm{dl}$; triglyceride (TG), $394 \mathrm{mg} / \mathrm{dl}$; and HDL cholesterol, $33.7 \mathrm{mg} / \mathrm{dl})$. The uric acid level was slightly high $(8.6 \mathrm{mg} / \mathrm{dl}$, normal range $3.4-7.8 \mathrm{mg} / \mathrm{dl})$. The serum $\gamma$-GTP level was high $(89 \mathrm{mU} / \mathrm{ml}$; normal range, $\leqq 40 \mathrm{mU} / \mathrm{ml}$ ). Other biochemical examinations showed normal results. Examination of the proband's family members was not possible.

\section{Apo E phenotyping}

Plasma apo E phenotypes were determined by 2-DE according to the method of O'Farrell (1975) with slight modifications to detect apo $\mathrm{E}$ variants with the basic PI (Yamanouchi et al. 1994). The apo E spots on the slab gels were confirmed by immunoblotting with an anti-human apo E antibody (Cappel Laboratories Inc., Malvern, PA, USA).

PCR amplification and SSCP analysis of the apo $E$ gene

As shown in Table 1, the PCR primers that we designed based on the nucleotide sequences of the apo $E$ gene (Paik et al. 1985) spanned all of the protein coding sequences. The target DNA was amplified using Taq DNA polymerase (AmpliTaq, Perkin Elmer, Cetus, Norwalk, CT, USA), performed in 36 cycles, each consisting of denaturation at $95^{\circ} \mathrm{C}$ for $1 \mathrm{~min}$, annealing at $69^{\circ}-73^{\circ} \mathrm{C}$ for $2 \mathrm{~min}$, and extension at $73^{\circ} \mathrm{C}$ for $2 \mathrm{~min}$ after preheating at $95^{\circ} \mathrm{C}$ for $5 \mathrm{~min}$.

SSCP analysis was carried out essentially according to the method described previously (Orita et al. 1989; Bannai et al. 1996). One microliter of the amplified solution was mixed with $7 \mu$ l of denaturing solution (95\% formamide, $20 \mathrm{mM}$ ethylenediaminetetraacetate (EDTA), $0.05 \%$ bromophenol blue, and $0.05 \%$ xylene cyanol FF). The mixture was denatured at $95^{\circ} \mathrm{C}$ for $5 \mathrm{~min}$ and immediately cooled on ice, and $1 \mu \mathrm{l}$ of the mixture was applied to a $10 \%$ polyacrylamide gel (acrylamide monomer:bisacrylamide $=49: 1$, with $5 \%$ glycerol). Electrophoresis was carried out in $45 \mathrm{mM}$ Tris-borate $(\mathrm{pH} 8.0) / 1 \mathrm{mM}$ EDTA at $37^{\circ} \mathrm{C}$ or $45^{\circ} \mathrm{C}$, and a constant current of $40 \mathrm{~mA}$ was applied for $2 \mathrm{~h}$. A minigel electrophoresis apparatus equipped with a constant temperature control system $\left(90 \times 80 \times 1 \mathrm{~mm}^{3}, \mathrm{AE}-6410\right.$ and AE-6730, ATTO, Tokyo, Japan) was used. The electrophoretic temperature is indicated in Table 1. The SSCP patterns were visualized by silver staining (Daiichi, Tokyo, Japan).

DNA sequence analysis

PCR products showing aberrant band patterns by SSCP analysis were ligated into a pCR vector using a TA cloning kit (Invitrogen, San Diego, CA, USA) and their sequences determined following the dideoxy chain termination method. Sequencing was carried out with an automated sequencer (377XL, Applied Biosystems, Foster city, CA, USA) using the ABI PRISM Big Dye Terminator Cycle Sequencing Ready Reaction kit.

Measurement of lipoprotein lipid and apolipoprotein levels in the serum

The serum levels of TC, TG, high-density lipoprotein cholesterol (HDL-C), apo B, apo E, apo AI, apo AII, apo CII, and apo CIII were measured according to the method of Yamanouchi et al. (1994).

Plasma lipoproteins were subjected to agarose gel electrophoresis using the Pol-E-Film system (Nihon Syoji, Osaka, Japan) and visualized by diformazan staining (cholesterol staining). Densitometric scanning of the gels was 
Table 1. Primers of exons 3 and 4 of apo E gene used for polymerase chain reaction (PCR) and single strand conformation polymorphism (SSCP)

\begin{tabular}{|c|c|c|c|c|c|c|}
\hline \multirow[b]{2}{*}{$\begin{array}{l}\text { Name of } \\
\text { primer }\end{array}$} & \multirow[b]{2}{*}{ Primer sequence } & \multirow[b]{2}{*}{ Position } & \multirow[b]{2}{*}{$\begin{array}{l}\text { Product } \\
\text { size (bp) }\end{array}$} & \multicolumn{2}{|l|}{ PCR } & \multirow{2}{*}{$\begin{array}{l}\text { SSCP } \\
\begin{array}{l}\text { Electrophoretic } \\
\text { temperature }\end{array}\end{array}$} \\
\hline & & & & $\begin{array}{l}\text { Polymerizing } \\
\text { temperature }\end{array}$ & $\begin{array}{l}\text { Reaction } \\
\text { mixture }\end{array}$ & \\
\hline APOE-F1 & 5'-TCA CCC TGC CCA CCA TGG CTC CA-3' & \multirow{2}{*}{$\begin{array}{l}2700-3060 \\
\text { (exon 3) }\end{array}$} & \multirow{2}{*}{361} & \multirow{2}{*}{$69^{\circ} \mathrm{C}$} & \multirow{2}{*}{ A } & \multirow{2}{*}{$37^{\circ} \mathrm{C}$} \\
\hline APOE-R1 & 5'-GGT ATA GCC GCC CAC CAG GAG G-3' & & & & & \\
\hline APOE-F2 & 5'-TCC CCC GCC TCC CCA CTG TGC GAC-3' & \multirow{2}{*}{$\begin{array}{l}3546-3825 \\
\text { (exon 4) }\end{array}$} & \multirow{2}{*}{280} & \multirow{2}{*}{$73^{\circ} \mathrm{C}$} & \multirow{2}{*}{$\mathrm{B}$} & \multirow{2}{*}{$37^{\circ} \mathrm{C}$} \\
\hline APOE-R2 & 5'-GGC GAG GCG CAC CCG CAG CTC CTC-3' & & & & & \\
\hline APOE-F3 & 5'-CTG GGC GCG GAC ATG GAG GAC GT-3' & \multirow{2}{*}{$\begin{array}{l}3721-4035 \\
\text { (exon 4) }\end{array}$} & \multirow[b]{2}{*}{315} & \multirow[b]{2}{*}{$73^{\circ} \mathrm{C}$} & \multirow[b]{2}{*}{$\mathrm{B}$} & \multirow[b]{2}{*}{$45^{\circ} \mathrm{C}$} \\
\hline APOE-R3 & 5'-CTG GGC CCG CTC CTG TAG CGG CT-3' & & & & & \\
\hline APOE-F4 & 5'-CTC AGC GCC ATC CGC GAG CGC CT-3' & \multirow{2}{*}{$\begin{array}{l}3931-4220 \\
\text { (exon 4) }\end{array}$} & \multirow{2}{*}{290} & \multirow{2}{*}{$73^{\circ} \mathrm{C}$} & \multirow{2}{*}{$\mathrm{B}$} & \multirow{2}{*}{$37^{\circ} \mathrm{C}$} \\
\hline APOE-R4 & 5'-TCC ACC AGG GGC TCG AAC CAG C-3' & & & & & \\
\hline APOE-F5 & 5'-GGC CCA GCA GAT ACG CCT GCA G-3' & \multirow{2}{*}{$\begin{array}{l}4149-4384 \\
\text { (exon 4) }\end{array}$} & \multirow{2}{*}{236} & \multirow{2}{*}{$73^{\circ} \mathrm{C}$} & \multirow[b]{2}{*}{ A } & \multirow{2}{*}{$37^{\circ} \mathrm{C}$} \\
\hline APOE-R5 & 5'-CTC CCG CTG CAG GCT GCG CGG A-3' & & & & & \\
\hline
\end{tabular}

The nucleotide numbers of the apo E gene according to Paik et al. (1985)

A, $500 \mathrm{mM} \mathrm{KCl}, 100 \mathrm{mM}$ Tris- $\mathrm{HCl}(\mathrm{pH} 8.4), 15 \mathrm{mM} \mathrm{MgCl}$, and $200 \mathrm{mM}$ gelatin; $\mathrm{B}, 500 \mathrm{mM} \mathrm{KCl}, 100 \mathrm{mM}$ Tris- $\mathrm{HCl}(\mathrm{pH} 8.8), 15 \mathrm{mM} \mathrm{MgCl}, 1 \%$ Triton, and $10 \%$ dimethylsulfoxide

performed with a dual-wavelength flying-spot scanner densitometer (CS-9000, Shimazu, Kyoto, Japan).

\section{Results}

Apo E5ss phenotype in 2-DE

Figure 1 shows the 2-DE patterns of apo E5ss, together with the data for its identification on the gel by immunoblotting. Apo E5ss was in the position apo E5 by IEF and had a slower migration than that of apo E3 by SDS-PAGE. The spot size of apo E5ss was much smaller than that of apo E3.

Detection of the novel apo E variants and nucleotide sequences of apo E5ss

Figure 2 shows the SSCP patterns of the PCR products amplified using the primer pair APOE-F3 and APOE-R3. We clearly distinguished apo E5ss from the common apo E alleles (apo E2, E3 and E4) and apo E5s. The dots indicate the band of the novel variant, E5ss. This indicates that the mutation in nucleotides 3721-4035 (numbering based on the published sequence) (Paik et al. 1985) results in the formation of apo E5ss. The other PCR products (primer pairs: APOE-F1 and APOE-R1, APOE-F2 and APOE-R2, APOE-F4 and APOE-R4, APOE-F5 and APOE-R5) of apo E3/5ss were identical to apo E3 as determined by PCRSSCP analysis.

DNA sequencing with cloning was carried out for the PCR products amplified using the primer pair APOE-F3

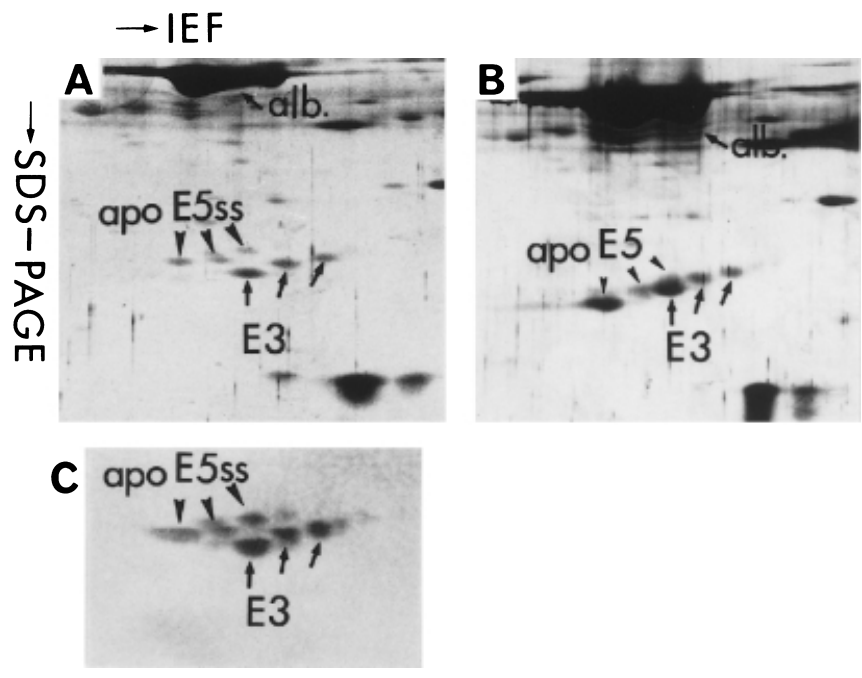

Fig. 1. Two-dimensional gel electrophoresis patterns of apo E5ss. A Silver staining of apolipoprotein E3/5ss (apo E3/5ss). B Silver staining of apo E3/5. C Immunoblotting of apo E3/5ss using specific antibody of apo E. Isoelectric focusing $(I E F)$ is from left to right and sodium dodecyl sulfate-polyacrylamide gel electrophoresis $(S D S-P A G E)$ is from top to bottom. Albumin is shown as alb. Apo E5ss is in the position apo E5 by IEF and has a slower migration than that of apo E3 by SDS-PAGE

and APOE-R3. Sequencing of the apo E5ss gene from the proband revealed a tandem repeat of eight amino acids resulting from the 24-bp insertion, that is, E5ss [APOE, 24BP INS, DUP CODONS 135-142]. Amino acids encoded by nucleotides $135-142$ were the same as those encoded by nucleotides 143-150 (numbering based on the published 
sequence) (Paik et al. 1985) (Fig. 3). Half of the clones that we analyzed showed the same sequence as the sequence mentioned earlier, because of the heterozygosity of apo E5ss of the proband. The nucleotide sequence of the other protein-coding region of the apo $E$ gene was identical to the published nucleotide sequence (Paik et al. 1985; Rall et al. 1982b).

Lipid levels of proband with apo E5ss

The lipoprotein profiles of the proband with apo E5ss indicated hypertriglyceridemia (serum TG, $394 \mathrm{mg} / \mathrm{dl}$ ). The serum apo CII and apo CIII levels were markedly elevated at $14.0 \mathrm{mg} / \mathrm{dl}$ (normal range, $1.1-5.0 \mathrm{mg} / \mathrm{dl}$ ) and $33.8 \mathrm{mg} / \mathrm{dl}$

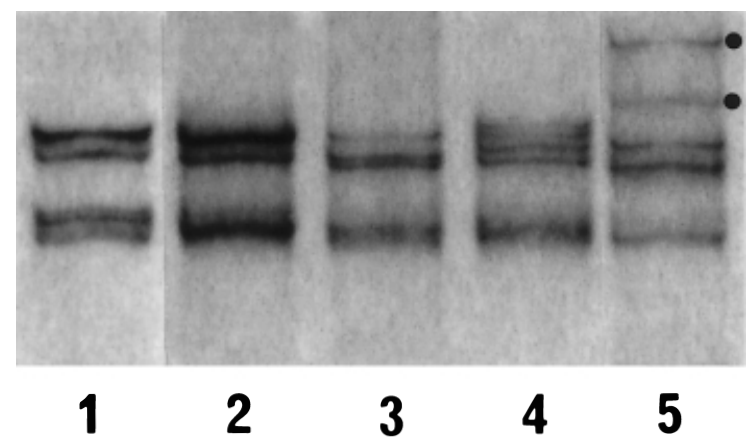

Fig. 2. Polymerase chain reaction-single strand conformation polymorphism analysis of apo E variants. Lane 1, apo E2/3; lane 2, apo E3/ 3 (most common type); lane 3, apo E3/4; lane 4, apo E4/5s (our previous reported case); lane 5, apo E3/5ss (proband). PCR products were amplified with the primer pair (APOE-F3 and APOE-R3). Dots indicate the bands of the novel apo E5ss (normal range, $4.0-14.0 \mathrm{mg} / \mathrm{dl}$ ), respectively. The concentrations of the other apolipoproteins in the proband were within the normal range (apo AI, $142 \mathrm{mg} / \mathrm{dl}$; apo AII, $33 \mathrm{mg}$ / $\mathrm{dl}$; apo B, $123 \mathrm{mg} / \mathrm{dl}$; apo E, $4.5 \mathrm{mg} / \mathrm{dl})$. Cholesterol-stained agarose gel electrophoresis also revealed higher levels of cholesterol-rich pre- $\beta$ lipoprotein (Fig. 4). This pattern was similar to that of samples from patients with type IV hyperlipidemia.

\section{Discussion}

We present a novel apo E5 variant, E5ss, that was detected by PCR-SSCP analysis and sequencing using newly designed primer pairs (Table 1). The reaction conditions for PCR and SSCP, in particular the temperature for electrophoresis during SSCP analysis, were strictly regulated. The primers included exons 3 and 4 and the neighboring intron, which contain the entire protein-coding region of the apo $E$ gene. Thus, this method was useful for rapid detection of almost all the variants of the apo E allele, as shown in Fig. 2 . In lane 5 , apo E3/5ss from this proband was clearly distinguished from the common apo E3/3 in lane 2, as the two dots indicate new bands of apo E5ss. In lane 4, apo E4/5s from our previous case (Yamanouchi et al. 1994) was also distinguished from the common apo E3/3 in lane 2. Moreover, apo E2/3 (lane 1) and apo E3/4 (lane 4), which had the classical apo E2 and E4 missense mutations at nucleotide positions 158 and 112, were distinguished from apo E3/3.

The denaturing gradient gel electrophoresis method was also used to detect apo E variants (van den Maagdenberg et al. 1993). Methods using the allele-specific oligonucle-
Fig. 3. Partial sequence chromatography of exon 4 in apo E5ss compared with that in apo E3. There is a 24-bp insertion at position 3813 or 3847 . This tandem repeat led to insertions of eight amino acids at position 135 or 142 apo E5ss
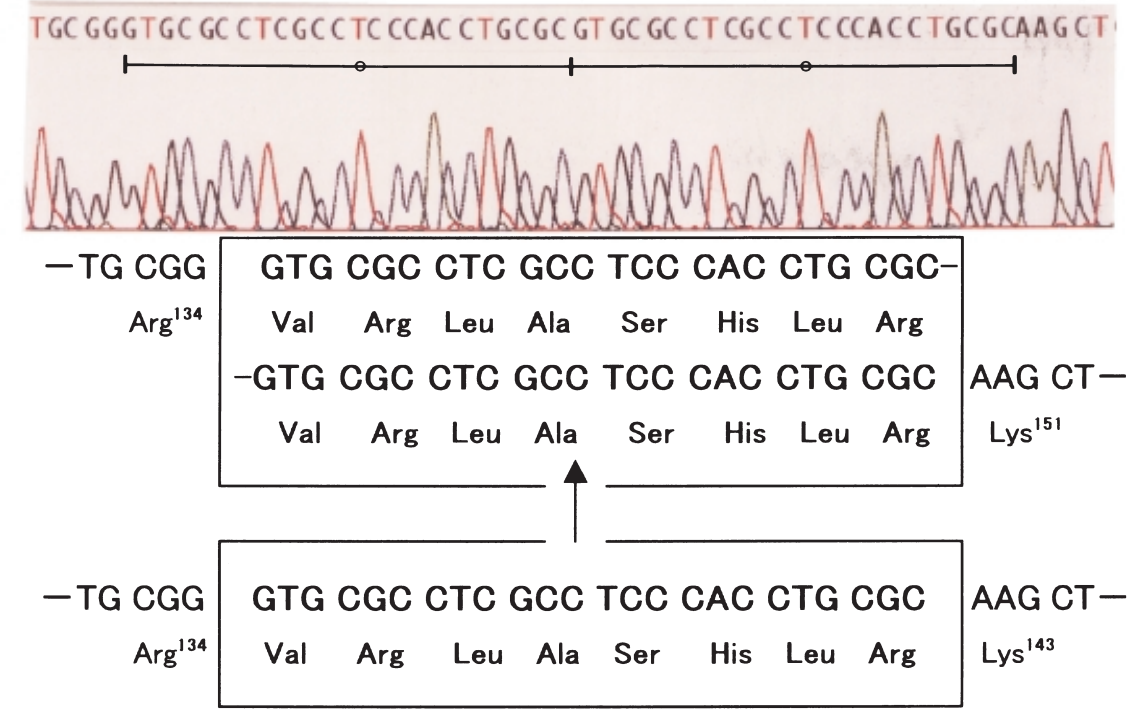

TGCG GGT GC GC C TC GC CTC CCAC CTGCGCAAGCTI

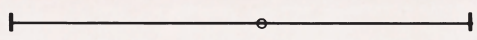

apo E3

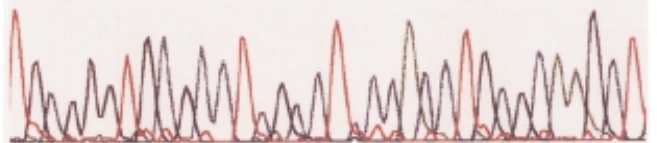


otide probe and PCR (Emi et al. 1988), or restriction fragment length polymorphism (Klasen et al. 1987; Tsai et al. 1993) enabled detection of the known variants only. There is a possibility that some unknown apo $\mathrm{E}$ variants are misclassified as apo E3.

DNA sequence analysis clarified that the novel apo E variant, apo E5ss, has a 24-bp insertion (Fig. 3). The 24-bp insertion in apo E5ss may be caused by slipped mispairing, resulting in a tandem duplication (Fig. 5). Amino acid residues 135-142 [24-BP INS, DUP CODONS 135-142] were duplicated. Another mechanism of duplication is homologous unequal recombination (Antonarakis et al. 2001). Variations of partial duplication of $45 \mathrm{bp}$ (COL2A1) have been reported. The duplication of $24 \mathrm{bp}$ of apo E5ss may be too small for homologous unequal recombination. In the case of slipped mispairing, a similar sequence exists in the original

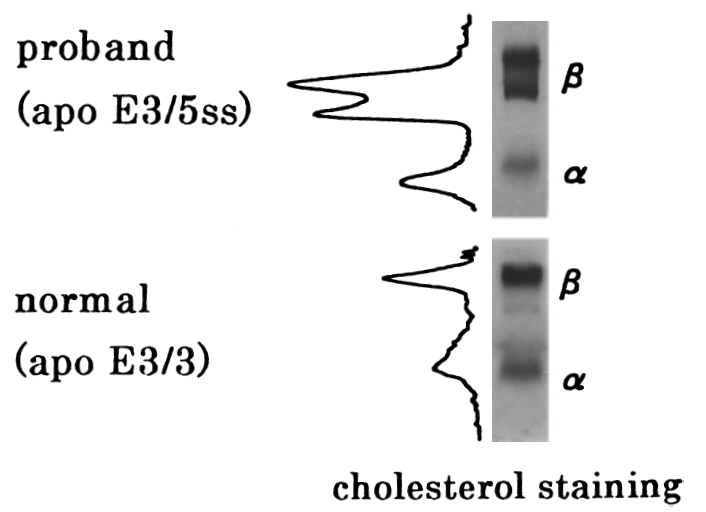

Fig. 4. Agarose gel electrophoresis of plasma lipoproteins visualized by cholesterol staining. This shows abundant pre- $\beta$ lipoproteins in the proband (apo E3/5ss)
DNA sequence and mispairing causes a tandem repeat in that sequence (Efstratiadis et al. 1980; Cooper and Krawczak 1991; Yamakawa-Kobayashi et al. 1993). This is consistent with the large size of the PCR product of apo E5ss using the primer pair APOE-F3 and APOE-R3 (data not shown). Moreover, based on the 2-DE pattern (Fig. 1), apo E5ss migrated more slowly than apo E3 in IEF, and had a larger molecular weight than apo E3. Furthermore, these inserted amino acids contain two arginine residues, which are charged amino acids, this causes the PI of apo E5ss shift by two units toward the anode compared with apo E3.

The proband with apo E3/5ss had a typical type IV hyperlipidemia. The TC/TG ratio was 0.5 , which was consistent with the definition of type IV hyperlipidemia $(0.15<$ TC/TG $<0.6)$. In the proband's plasma, apo CII and apo CIII levels were elevated, but the TC level was normal. Agarose gel electrophoresis of plasma lipoproteins using the Pol-E film system by cholesterol staining showed high levels of the pre- $\beta$ lipoprotein (apo E3/E5ss) (Fig. 4). The chylomicron peak was not elevated. Because of the increased pre- $\beta$ lipoprotein level and normal TC level, the pre- $\beta$ lipoprotein (VLDL) of the proband became rich in cholesterol. There seem to be two possible reasons for these findings. One might be a deficiency in conversion of VLDL to LDL, resulting in an increase in the level of cholesterolrich VLDL. The other might be an abnormality in binding of VLDL with apo E5ss to the VLDL receptor because apo $\mathrm{E}$ is a ligand of the VLDL receptor. The VLDL receptor has five functional domains common to the LDL receptor. In the case of apo E5ss, the insertion might be located within the first half of the receptor-binding region of helix 4 (residues 136-150) (Wilson et al. 1991; Dong et al. 1998). Although the insertion may result in a helix 4 extension in the four-helix bundle of the amino-terminal domain, the
Fig. 5. Mechanisms for 24-bp insertion [APOE, 24-BP INS DUP CODONS 135-142]. Slipped mispairing may be generated between one of the direct repeats $(C T G C G)$ and the other complementary direct repeat $(G A C G C)$. Apo E5ss may have a 24-bp insertion caused by this slipped mispairing, resulting in a tandem duplication

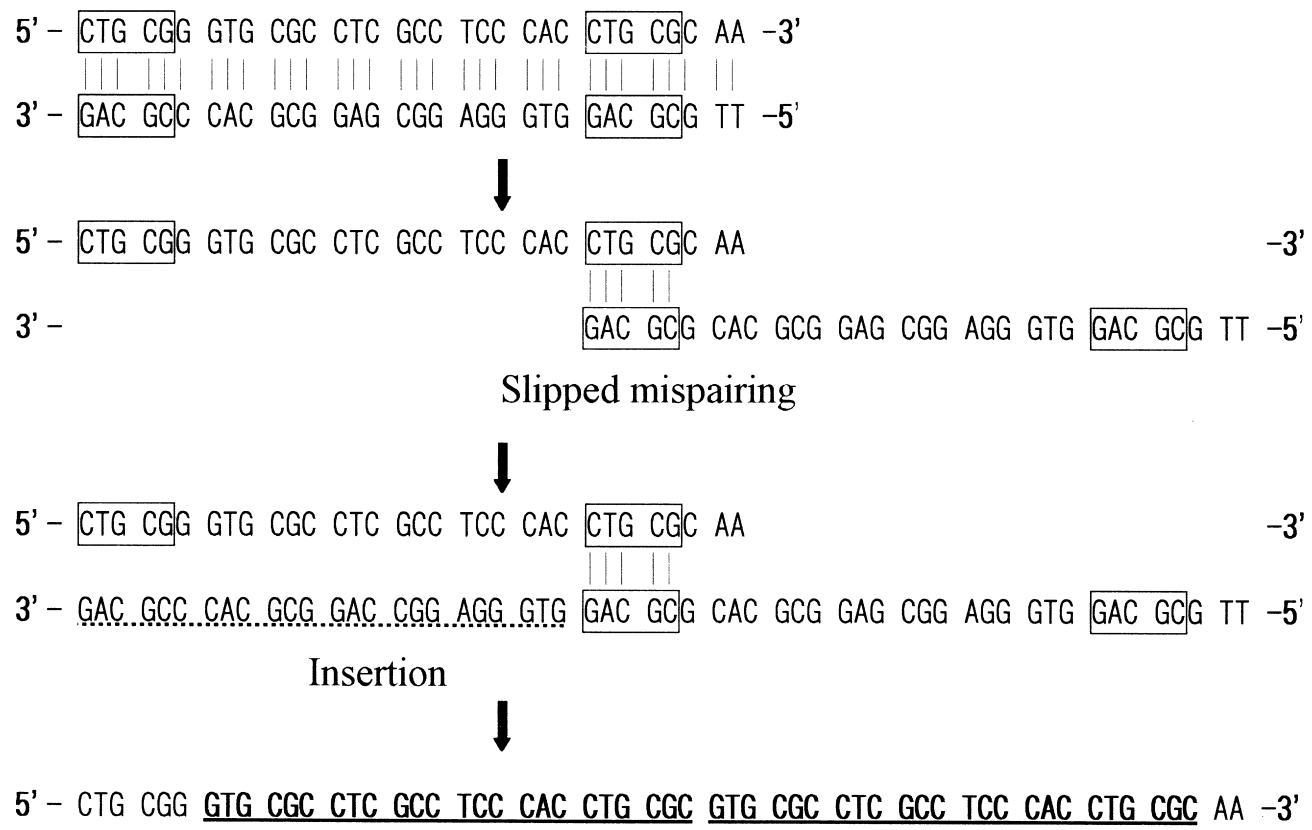
GAC GCG CAC GCG GAG CGG AGG GTG GAC GCG TT $-\mathbf{5}^{\prime}$ Slipped mispairing

$5^{\prime}$ - CTG CGG GTG CGC CTC GCC TCC CAC CTG CGC AA

3' - GAC GCC CAC GCG GAC CGG AGG GTG GAC GCG CAC GCG GAG CGG AGG GTG GAC GCG TT -5' Insertion

5' - CTG CGG GTG CGC CTC GCC TCC CAC CTG CGC GTG CGC CTC GCC TCC CAC CTG CGC AA -3' 
Table 2. Summary of seven apo E5 variants

\begin{tabular}{|c|c|c|c|c|c|c|}
\hline \multirow[b]{2}{*}{ Apo $E$ genotype $^{\mathrm{a}}$} & \multicolumn{2}{|l|}{ Lipid levels ${ }^{\mathrm{b}}$} & \multirow{2}{*}{$\begin{array}{l}\text { Binding } \\
\text { affinity }^{\mathrm{c}}\end{array}$} & \multirow{2}{*}{$\begin{array}{l}\text { Electric mobility } \\
\text { on SDS-PAGE }\end{array}$} & \multirow{2}{*}{$\begin{array}{l}\text { Previous } \\
\text { name }\end{array}$} & \multirow[b]{2}{*}{ Reference } \\
\hline & $\mathrm{TC}(\mathrm{mg} / \mathrm{dl})$ & TG (mg/dl) & & & & \\
\hline$E 3 K$ & $156-281$ & $65-226$ & $200 \%$ & fast & E5 & $\begin{array}{l}\text { Tajima et al. (1988) } \\
\text { Matsunaga et al. (1995) }\end{array}$ \\
\hline$E 13 K$ & $217-331$ & $56-196$ & & slightly fast & E5 & Mailly et al. (1991) \\
\hline$Q 81 K A N D C 112 R$ & 226 & 191 & & same & E5 Frankfurt & Ruzicka et al. (1993) \\
\hline P84R AND C112R & 226 & 147 & $100 \%$ & same & E5 & $\begin{array}{l}\text { Ordovas et al. (1987) } \\
\text { Wardell et al. (1991) }\end{array}$ \\
\hline 24-BP INS, DUP CODONS 135-142 & 181 & 394 & & slow & E5ss & Present report \\
\hline$E 171 K$ & 240 & 98 & & slightly slow & E5s & Yamanouchi et al. (1994) \\
\hline$E 212 K$ & $115-213$ & $52-170$ & $100 \%$ & & E5 & Feussner et al. (1996) \\
\hline
\end{tabular}

TC, total cholesterol; TG, triglyceride; SDS-PAGE, sodium dodecyl sulfate-polyacrylamide gel electrophoresis

${ }^{a}$ Genotype was coded according to OMIM

${ }^{\mathrm{b}}$ Lipid levels range of probands. Blood samples were taken after an overnight fast

${ }^{\mathrm{c}}$ Binding affinity for low-density lipoprotein receptor compaired with apo E3/3

${ }^{\mathrm{d}}$ Compaired to electric mobility of apo E3 on SDS-PAGE

original sequence of the receptor-binding region may be retained (Fig. 3). This may be one of the reasons that the LDL levels of the patient with apo E5ss were within the normal range.

The secretion level of apo E5ss seems to be lower than that of apo E3, although the plasma apo E level of the proband was within the normal range. This is because the apo E5ss spot on the 2-DE gel is smaller than the apo E3 spot (about one-third according to image analysis using NIH imaging software). This may be explained by the maturation process of the apo $\mathrm{E}$ protein rather than by the decrease in its expression level or by the degradation of the protein. Because of the extra eight amino acids on the site of the coding region in apo E5ss, the blood apo E level in the homozygote of apo E5ss is expected to be low, which is likely to result in severe symptoms. On the other hand, the proband's plasma levels of apo $\mathrm{E}$, which is the heterozygote of apo E3, were normal $(4.5 \mathrm{mg} / \mathrm{dl}$; normal range, 2.2 $6.4 \mathrm{mg} / \mathrm{dl}$ ). It may be presumed that sufficient secretion of normal apo E3 may protect an individual against other lipid abnormalities.

As for the duplicate insertion of apo E, apo E3-Leiden has been reported (Wardell et al. 1989; Knijff et al. 1991). This is a tandem duplication of seven amino acids [APOE, 21-BP INS, DUP CODONS 121-127]. The heterozygote of E3-Leiden was characterized with a high cholesterol ratio, high VLDL fraction, high LDL fraction, and high apo E levels. All carriers of apo E3-Leiden present type III hyperlipidemia, and have different symptoms from those of apo E5ss carriers.

The allele frequency of apo E5 in Japan is estimated at about 0.005 (Yamanouchi et al. 1994; Matsunaga et al. 1995). This is high next to the three common types of apo $E$ (apo E3, E4, E2) and apo E7. The incidence of apo E5ss may be rare. Among 806 persons having a physical examination in Tokyo, only 1 had apo E5ss. Seven apo E5 variants with different DNA sequences, including that in the present report, and their characteristics were compared (Table 2) (Tajima et al. 1988; Matsunaga et al. 1995; Mailly et al. 1991; Ruzicka et al. 1993; Ordovas et al. 1987; Wardell et al. 1991; Yamanouchi et al. 1994; Feussner et al. 1996). The apo E5s, which we described previously (Yamanouchi et al. 1994), was determined to be caused by a substitution, resulting in [APOE, E171K] using PCR-SSCP and DNA sequence analysis (data not shown). In apo E5 variants, most of the mutations were due to an $\mathrm{E} \rightarrow \mathrm{K}$ substitution. Although the electric mobility during SDS-PAGE of apo E5 [APOE, $\mathrm{E} 3 \mathrm{~K}$ ] is fast compared with apo E3, that of apo E5s [APOE, E171K] is slow. The mobility of apo E5ss [APOE, 24-BP INS, DUP CODONS 135-142] is slower than that of apo E5s. There were no marked tendencies between the apo E5 genotype and lipid abnormality. Thus, investigations of many more apo E5 variants are needed to elucidate the function of apo E.

Acknowledgments The authors would like to thank Takeo Juji, Yoshihide Ishikawa, Ling Lin (Japanese Red Cross Central Blood Center), Karo Tanaka (Teikyo University School of Medicine), Ryunosuke Miyazaki (Kudanzaka Hospital, Tokyo), Shigeru Tsuchiya, Tadao Arinami, Kimiko Kobayashi-Yamakawa, and Kaoru J. Takano (University of Tsukuba). This study was partly supported by a Grantin-Aid for Scientific Research from the Ministry of Education, Culture, Sports, Science and Technology, Japan.

\section{References}

Antonarakis SE, Krawczak M, Cooper DN (2001) The nature and mechanisms of human gene mutation. In: Scriver CR, Braudet AL, Sly WS, Valle DV (eds) The metabolic and molecular bases of inherited disease, 8th edn. McGraw-Hill, New York, pp 343-378

Bannai M, Tokunaga K, Lin L, Ogawa A, Fujisawa K, Juji T (1996) HLA-B40, B18, B27, and B37 allele discrimination using groupspecific amplification and SSCP method. Hum Immunol 46:107-113

Breslow JL, Zannis VI, SanGiacomo TR, Third JL, Tracy T, Glueck CJ (1982) Studies of familial type III hyperlipoproteteinemia using as a genetic marker the apoE phenotype E2/2. J Lipid Res 23:1224-1235

Cooper DN, Krawczak M (1991) Mechanisms of insertional mutagenesis in human genes causing genetic disease. Hum Genet 87:409415

Corder EH, Saunders AM, Strittmatter WJ, Schmechel DE, Gaskell PC, Small GW, Roses AD, Haines JL, Pericak-Vance MA (1993) Gene does of apolipoprotein E type 4 allele and the risk of Alzheimer's disease in late onset families. Science 261:921-923

Dong LM, Innerarity TL, Arnold KS, Newhouse YM, Weisgraber KH (1998) The carboxyl terminus in apolipoprotein E2 and the seven 
amino acid repeat in apolipoprotein E-Leiden: role in receptorbinding activity. J Lipid Res 39:1173-1180

Dong LM, Yamamura T, Yamamoto A (1990) Enhanced binding activity of an apolipoprotein E mutant, apo E5, to LDL receptors on human fibroblasts. Biochem Biophys Res Commun 168:409-414

Efstratiadis A, Posakony JW, Maniatis T, Lawn RM, O'Connell C, Spritz RA, DeRiel JK, Forget BG, Weissman SM, Slightom JL, Blechl AE, Smithies O, Baralle FE, Shoulders CC, Proudfoot NJ (1980) The structure and evolution of the Human $\beta$-globin gene family. Cell 21:653-668

Emi M, Wu LL, Robertson MA, Myers RL, Hegele RA, Williams RR, White R, Lalouel JM (1988) Genotyping and sequence analysis of apolipoprotein E isoforms. Genomics 3:373-379

Feussner G, Scharnagl H, Scherbaum C, Acar J, Dobmeyer J, Lohrmann J, Wieland H, Marz W (1996) Apolipoprotein E5 $\left(\mathrm{Glu}_{212} \rightarrow\right.$ Lys): increased binding to cell surface proteoglycans but decreased up take and lysosomal degradation in cultured fibroblasts. J Lipid Res 37:1632-1645

Havel RJ, Kotite L, Kane JP, Tun P, Bersot T (1983) Atypical familial dysbetalipoproteinemia associated with apolipoprotein phenotype E3/3. J Clin Invest 72:379-387

Klasen EC, Talmud PJ, Havekes L, de Wit E, van der Kooij-Meijs E, Smit M, Hansson G, Humphries SE (1987) A common restriction fragment length polymorphism of the human apolipoprotein $\mathrm{E}$ gene and its relationship to type III hyperlipidaemia. Hum Genet 75:244247

Knijff PD, van den Maagdenberg JM, Stalenhoef AFH, Leuven JAG, Demacker PNM, Kuyt LP, Frants RR, Havekes LM (1991) Familial dysbetalipoproteinemia associated with apolipoprotein E3-Lieden in an extended multigeneration pedigree. J Clin Invest 88:643-655

Lalazar A, Weisgraber KH, Rall SC Jr, Giladi H, Innerarity TL, Levanon AZ, Boyles JK, Amit B, Gorecki M, Mhaley RW, Vogel T (1988) Site-specific mutagenesis of human apolipoprotein E. J Biol Chem 263:3542-3545

Maeda H, Nakamura H, Kobori S, Okada M, Niki H, Ogura T, Hiraga S (1989) Molecular cloning of a human apolipoprotein E variant: E5 $\left(\mathrm{Glu}_{3} \rightarrow \mathrm{Lys}_{3}\right)$. J Biochem 105:491-493

Mahley RW (1988) Apolipoprotein E: cholesterol transport protein with expanding role in cell biology. Science 240:622-630

Mailly F, Xu C, Xhignesse M, Lussier-Cacan S, Talmud PJ, Davignon J, Humphries SE, Nestruck AC (1991) Characterization of a new apolipoprotein E5 variant detected in two French-Canadian subjects. J Lipid Res 32:613-620

Matsunaga A, Sasaki J, Moriyama K, Arakawa F, Takeda Y, Nishi K, Hidaka K, Arakawa K (1995) Population freguency of apolipoprotein E5 (Glu3 $\rightarrow$ Lys) and E7 (Glu244 $\rightarrow$ Lys, Glu245 $\rightarrow$ Lys) variants in western Japan. Clin Genet 48:93-99

McKusick VA (1998) Mendelian inheritance in man. A catalog of human genes and genetic disorders, 12th edn, vol 2. The Johns Hopkins University Press, London, pp 181-191 OMIM: http:// www.ncbi.nlm.nih.gov/Omim/searchomim.html

Noguchi S, Murakami K, Yamada N (1993) Apolipoprotein E genotype and Alzheimer's disease. Lancet 342:737-738

O'Farrell PH (1975) High resolution two-dimensional electrophoresis of proteins. J Biol Chem 250:4007-4021

Ordovas JM, Litwack-Klein L, Wilson PWF, Schaefer MM, Schaefer EJ (1987) Apolipoprotein E isoform phenotyping methodology and population frequency with identification of apoE1 and apoE5 isoforms. J Lipid Res 28:371-380

Orita M, Suzuki Y, Sekiya T, Hayashi K (1989) Rapid and sensitive detection of protein mutations and DNA polymorphisms using the polymerase chain reaction. Genomics 5:874-879

Paik YK, Chang DJ, Reardon CA, Davies GE, Mahley RW, Taylor JM (1985) Nucleotide sequence and structure of the human apolipoprotein E gene. Proc Natl Acad Sci USA 82:3445-3449

Poirier J, Davignon J, Bouthillier D, Kogan S, Bertrand P, Gauthier S (1993) Apolipoprotein E polymorphism and Alzheimer's disease. Lancet 342:697-699

Rall SC Jr, Newhouse YM, Clarke HRG, Weisgraber KH, McCarthy BJ, Mahley RW, Bersot T (1989) Type III hyperlipoproteinemia associated with apolipoprotein E phenotype E3/3. Structure and genetics of an apolipoprotein E3 variant. J Clin Invest 83:10951101

Rall SC Jr, Weisgraber KH, Mahley RW (1982a) Human apolipoprotein E: the complete amino acid sequence. J Biol Chem 257:4171-4178

Rall SC Jr, Weisgraber KH, Innerarity TL, Mahley RW (1982b) Structural basis for receptor binding heterogeneity of apolipoprotein $\mathrm{E}$ from type III hyperlipoproteinemic subjects. Proc Natl Acad Sci USA 79:4696-4700

Ruzicka V, Marz W, Russ A, Fisher E, Mondorf W, Gross W (1993) Characterization of the gene for apolipoprotein E5-Frankfurt $\left(\mathrm{Glu}^{81} \rightarrow \mathrm{Lys}, \mathrm{Cys}^{112} \rightarrow \mathrm{Arg}\right)$ by polymerase chain reaction, restriction isotyping and temperature gradient gel electrophoresis. Electrophoresis 14:1032-1037

Saunders AM, Strittmatter WJ, Schmechel D, George-Hyslop PHSt, Pericak-Vance MA, Joo SH, Rosi BL, Gusella JF, CrapperMacLachlan DR, Alberts MJ, Hulette C, Crain B, Goldgaber D, Roses AD (1993) Association of apolipoprotein E allele $\varepsilon 4$ with lateonset familial and sporadic Alzheimer's disease. Neurology 43:14671472

Tajima S, Yamamura T, Yamamoto A (1988) Analysis of apolipoprotein E5 gene from a patient with hyperlipoproteinemia. J Biochem 104:48-52

Tsai MY, Suess P, Schwichtenberg K, Eckfeldt JH, Yuan J, Tuchman M, Hunninghake D (1993) Determination of apolipoprotein E genotype by single-strand conformational polymorphism. Clin Chem 39:2121-2124

Utermann G, Langenbeck U, Beisiegel U, Weber W (1980) Genetics of the apolipoprotein E system in man. Am J Hum Genet 32:339347

van den Maagdenberg AMJM, Weng W, de Bruijn IH, de Knijff P, Funke H, Smelt AHM, Gevers Leuven JA, van't Hooft FM, Assmann G, Hofker MH, Havekes LM, Frants RR (1993) Characterization of five new mutants in the carboxylterminal domain of human apolipoprotein E: no cosegregation with severe hyperlipidemia. Am J Hum Genet 52:937-946

Wardell MR, Weisgraber KH, Havekes LM, Rall SC Jr (1989) Apolipoprotein E3-Leiden contains a seven-amino acid insertion that is a tandem repeat of residues 121-127. J Biol Chem 264:2120521210

Wardell MR, Rall SC Jr, Schaefer EJ, Kane JP, Weisgraber KH (1991) Two apolipoprotein E5 variants illustrate the importance of the position of additional positive charge on receptor-binding activity. $\mathbf{J}$ Lipid Res 32:521-528

Weisgraber KH, Innerarity TL, Mahley RW (1982) Abnormal lipoprotein recepter-binding activity of the human $\mathrm{E}$ apoprotein due to cysteine-arginine interchange at a single site. J Biol Chem 257:25182521

Wilson C, Wardell MR, Weisgraber KH, Mahley RW, Agard DA (1991) Three-dimensional structure of the LDL receptor-binding domein of human apolipoprotein E. Science 252:1817-1822

Yamakawa-Kobayashi K, Kobayashi T, Saku K, Arakawa K, Hamaguchi H (1993) Two novel frameshift mutations associated with the presence of direct repeats of the LDL receptor gene in familial hypercholesterolemia. Hum Genet 92:331-335

Yamamura T, Yamamoto A, Hiramori K, Nambu S (1984) A new isoform of apolipoprotein E - apo E-5 - associated with hyperlipidemia and atherosclerosis. Atherosclerosis 50:159-172

Yamanouchi Y, Arinami T, Tsuchiya S, Miyazaki R, Takaki H, Takano T, Hamaguchi H (1994) Apolipoprotein E5 and E7 in apparently healthy Japanese males: frequencies and relation to plasma lipid levels. Jpn J Hum Genet 39:315-325

Yoshizawa T, Yamakawa-Kobayashi K, Komatsuzaki Y, Arinami T, Oguni E, Mizusawa H, Shoji S, Hamaguchi H (1994) Doesdependent association of apolipoprotein $\mathrm{E}$ allele $\varepsilon 4$ with late-onset, sporadic Alzheimer's disease. Ann Neurol 36:656-659

Zannis VI, Just PW, Breslow JL (1981) Human apolipoprotein E isoprotein subclasses are genetically determined. Am J Hum Genet 33:11-24 